\title{
Covid 19 Early Warning Detection System
}

\section{DOI:10.36909/jer.ASSEEE.16103}

Sutono*, Selvia Lorena Br Ginting**, Senny Luckyardi***

\author{
*Departemen Teknik Elektro, Universitas Komputer Indonesia, Indonesia \\ **Departemen Sistem Komputer, Universitas Komputer Indonesia, Indonesia \\ ***Departemen Manajemen, Universitas Komputer Indonesia , Indonesia \\ *Corresponding Author: sutono@email.unikom.ac.id
}

\begin{abstract}
A mosque is a place of worship activities that is very crowded with people, especially if the mosque is located on the side of the road. Automatically, the mosque users are local people and outsiders who happen to cross the mosque. In the Covid-19 pandemic, anticipating the impact of its spread must be watched out, especially since this mosque is often visited by worshipers from outside (not the surrounding community). Inside the mosque, this aims to limit the number of worshipers in the mosque; the ultrasonic sensor functions to find out the people who are wrongly occupying the shaft or place of prayer with an indicator in the form of a buzzer. Thus this research aims to provide a solution to a sense of security and comfort to the local community and outsiders who will use the mosque to worship. In the mosque, a covid-19 early warning system has been implanted using three sensors, namely an infrared sensor, ultrasonic sensor, and infrared body temperature sensor. Based on reports in March 2021, there was a decrease in confirmed symptoms of Covid 19, which originally amounted to 82 people confirmed as Covid 19. After implementing the system, two reports were found to have died, 78 people said to be cured, and two people are still undergoing quarantine at their respective homes. Then enter the month of Ramadan in 2021, some reports confirm that Covid 19 is nil. It is a positive response that has a good impact on worshipers, especially those who use mosques as a means of worship. This data can be accessed through an application called "PeduliL Protects," which can be downloaded via the Android application in the play store under the zoning "Babakan Tarogong Village."
\end{abstract}




\section{INTRODUCTION}

The rapid development of technology makes researchers easier to conduct research. It was proven when researchers faced the Covid-19 pandemic. One of the problems faced is in the process of doing worship. The number of people entering the mosque is difficult to monitor because there are no sensors to detect people. To overcome the problem, an infrared sensor is implanted, which functions to move the door bars. It is intended if the number of congregants detected reaches the limit, the latch will automatically remain closed even though their body temperature is less than 37 degrees Celsius (Arfandi, A., \& Supit, Y. 2019).

To solve this problem, we tried to make a model system applied in a mosque; the idea of making a model system was inspired by several studies conducted. Armin Afandi, Yonal Supit, implemented an infrared sensor to detect the presence of objects (Arfandi, A., \& Supit, Y. 2019). Heady Dainty, application of the MLX9014 sensor to detect a person's body temperature without touching (Dianty, H. 2020). Ronaldo Muzawi, Yoyon Efendi, Unang, application of the HC-SR04 ultrasonic sensor to measure the distance of an object (Efendi et al., 2019). Based on the three studies that have been carried out, the researchers tried to combine the three studies into one using a model system in the form of a mosque. The MLX9014 sensor is embedded in it to measure the temperature of the worshipers who will perform worship activities. This infrared sensor functions to calculate the number of worshipers who are present.

The purpose of this study is to create a system model that is implemented in mosques. This system model functions to monitor the activities of the people in carrying out a series of worship in the mosque while still implementing the Covid-19 health protocol. It is done using several sensors, including the MLX9014 Infrared Body Temperature, which detects body temperature. If the detected temperature is less than 37 degrees Celsius, people can enter the mosque (Dianty, H. 2020). Monitoring in terms of the capacity of the people is made with the sensor latch described above.

Another obstacle is the distance between people at the time of praying has not been regulated so that the people cannot maintain their distance. Therefore, an ultrasonic sensor that can move to detect the distance of the people has to be installed. In this study, the distance is set to 1 meter, and if the distance changes, an alarm will sound. People get a warning to move at a certain distance (Efendi et al., 2019). 


\section{METHOD}

The method used in this research is to use a mapping of an area with a matrix concept to move an ultrasonic sensor. It can move horizontally and vertically to detect the presence of the first object with the second object (Puspitasari, W. D., \& Ilmi, D. K. 2019) (see Figure 1).

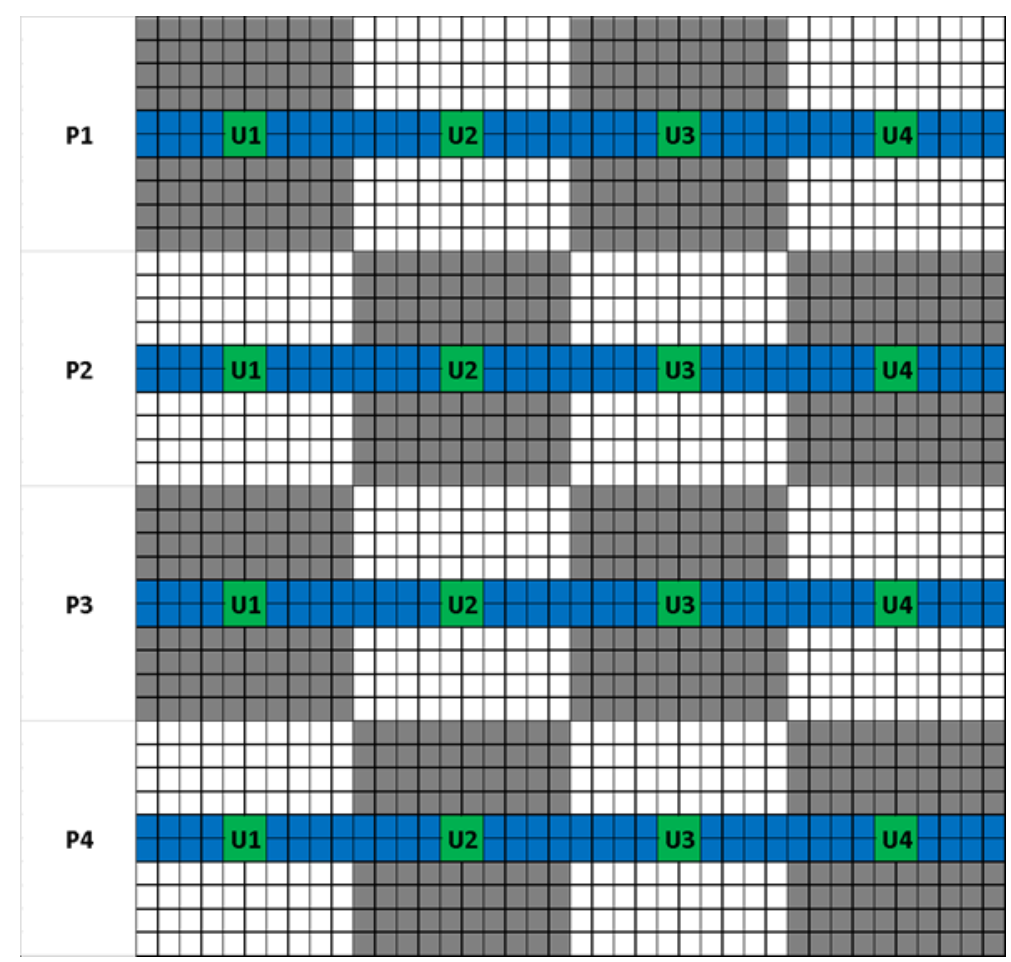

Figure 1 4x4 area matrix

The starting point of the matrix is at point P1 (there are four ultrasonic sensors, U1, U2, U3, and U4, with a distance between sensors of about 1 meter). This sensor will move from P1 to P2, P3, and P4 to detect people in the mosque. The object will be stored in the system memory. For example, at position P1 the U2 sensor detects an object, then the object at that point will be stored in system memory. The ultrasonic sensor will move to position P2. If an object is found, the object will be stored in system memory with a different address. So the sensor will move to position P4. If an object is found, then that object will be stored at a different system address.

After the ultrasonic sensor is in the P4 position, the system will then measure all the points that have been mapped in a certain area using the matrix concept. It calculates the distance between any two objects using the Pythagorean formula, if the distance between the two points is less than 1 meter, a warning alarm 
in the form of a buzzer will sound which indicates the presence of an object, in this case, the people, which is less than 1 meter away.

To calculate the distance between two objects or points, the researcher uses the Pythagoras formula $\mathrm{c}^{\wedge}$ $2=a^{\wedge} 2+b^{\wedge} 2$ where $c$ is the distance between two objects to be calculated for the distance value, $a$ is the location of the first object and b is the location of the second object (Triono, A. 2017; Soegoto et al., 2021; Pratama, W. H., \& Sumitra, I. D. 2020) (See Figure 2).

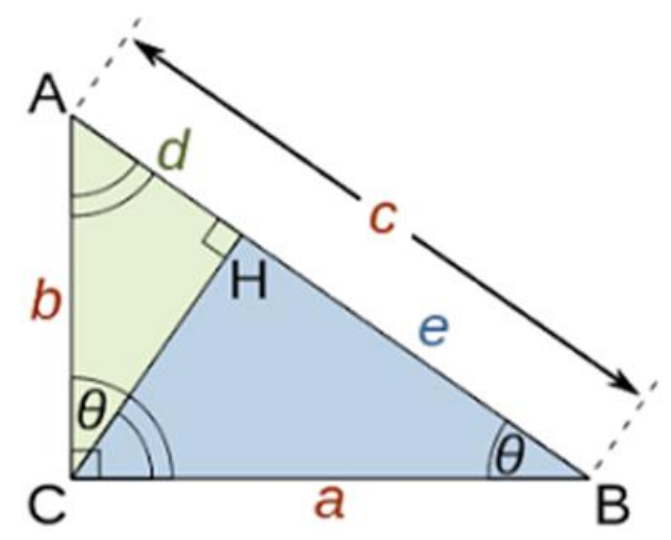

Figure 2 Pythagoras

Basically, to calculate the distance between two objects using the matrix method to find out the location of the first and second object points in a matrix area. Meanwhile, to calculate the distance between two objects using the Pythagorean formula (See Figure 3).

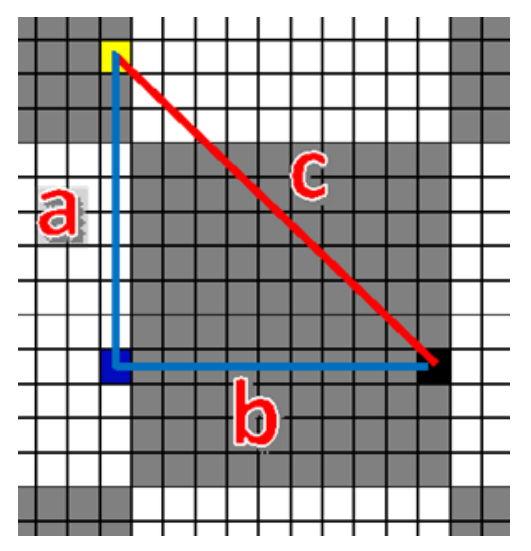

Figure 3 The matrix method and Pythagorean formula

To design Figure 2, we assume the estimated area distance is about 1 meter, where each estimated area has 100 coordinate points with a distance between the points of about 10 centimeters. For example, to 
calculate the case example in Figure 2. The distance between two points, namely the yellow and black dots using the Pythagorean formula, is that we first calculate the length of line a (the distance between the yellow dots and the blue dots) of about 10100 centimeter / 1 meter (Gao et al., 2020; Yang et al., 2020; Covino et al., 2020). Next, we calculate the length of line b (the distance between the blue dots and the black dots) of about 11 points or about 110 centimeters / 1.1 meters. So the distance between the yellow dot and the black dot (line length $\mathrm{c}$ ) is $\mathrm{c}^{\wedge} 2=\mathrm{a} 2+\mathrm{b} 2=12+1.1^{2}=1+1.21=2.21$ meters. So that the distance between these objects is $\sqrt{ } 2.21=1.4866$ meters.

\section{RESULTS AND DISCUSSION}

On 31 March 2020, President Jokowi held a Press Conference to announce to the public his policies and choices to address Covid 19 as a global pandemic currently facing the Indonesian people. At the press conference, President Jokowi stated that the Large-Scale Social Restrictions (PSBB) policy was chosen in response to Health Emergencies. Law No. 6/2018 on Health Quarantine is the legal basis for this anticipatory policy. The meaning of Large-Scale Social Restrictions is the limitation of certain activities of residents in an area suspected of being infected with Corona Virus Disease 2019 (Covid 19) in such a way as to prevent the possible spread of Covid 19.

At the press conference, President Jokowi also emphasized that Regional Governments should not apply their policies in their territories that are not by Central Government protocols. Local governments and private parties must comply with the PSBB determined by the central government. If they do not comply or obstruct the implementation of the PSBB, they can be charged with criminal sanctions since the beginning of the Covid 19 case that appeared in Wuhan, China. The central Government in Indonesia did not declare anything to the public. However, when viewed from the regional leaders, it turns out that they are more alert in dealing with the Covid 19 case. It makes it visible that there is a lack of coordination between the Central Government and Regional Governments in making policies. Even the policies issued by the central government and regional governments often overlap.

Amid concerns that the Covid 19 case that is needed by the community is the government to protect its citizens according to the mandate of the 1945 Constitution of the Republic of Indonesia, one of which is 
the policy in dealing with the Covid 19 case. Figures 4 - 10 are conditions for the spread of covid 19 with the period from May 2020 to March 2021.

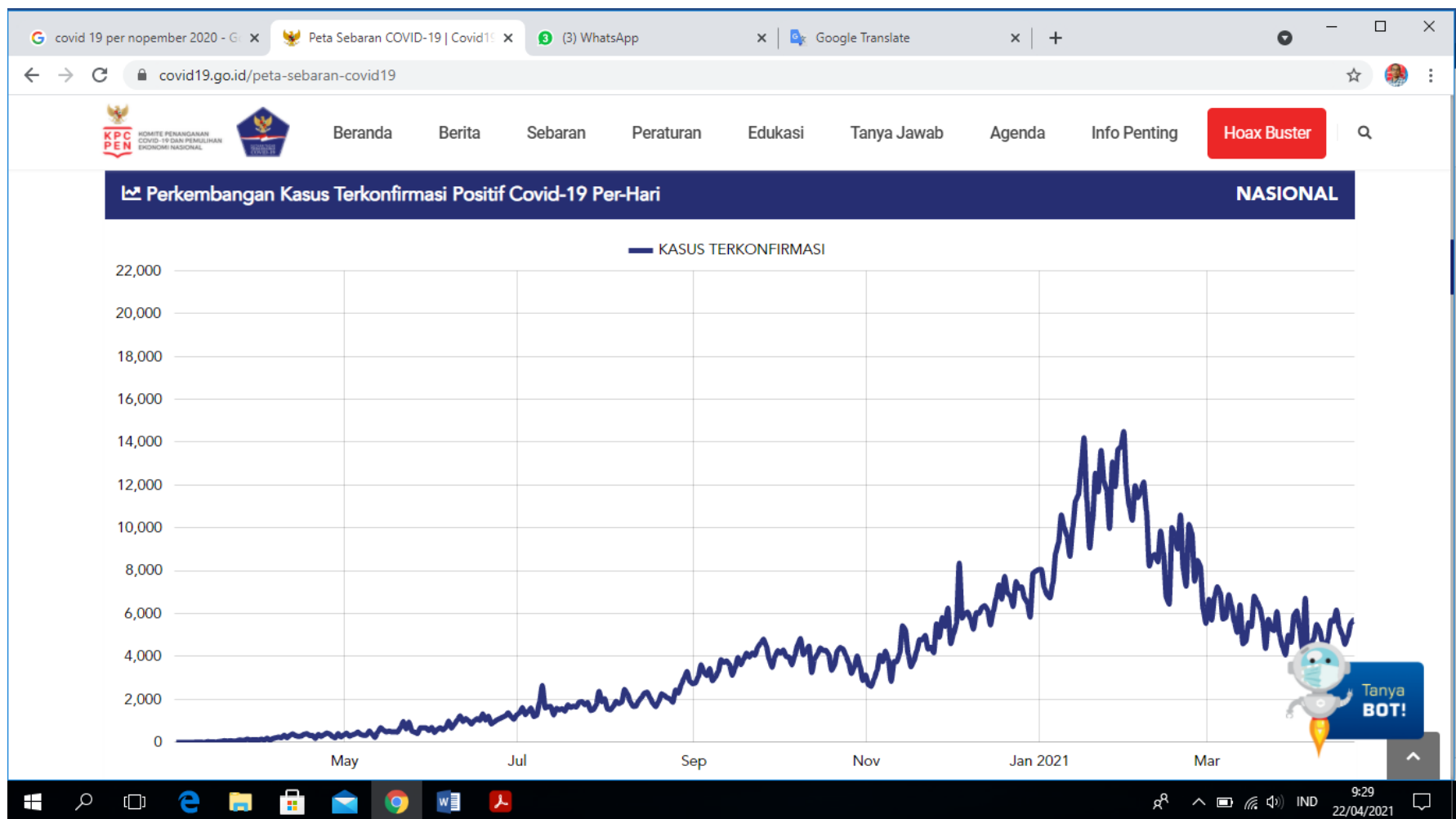

Figure 4 Development of positive confirmed cases of corona 19 for the period May 2020 to March 2021

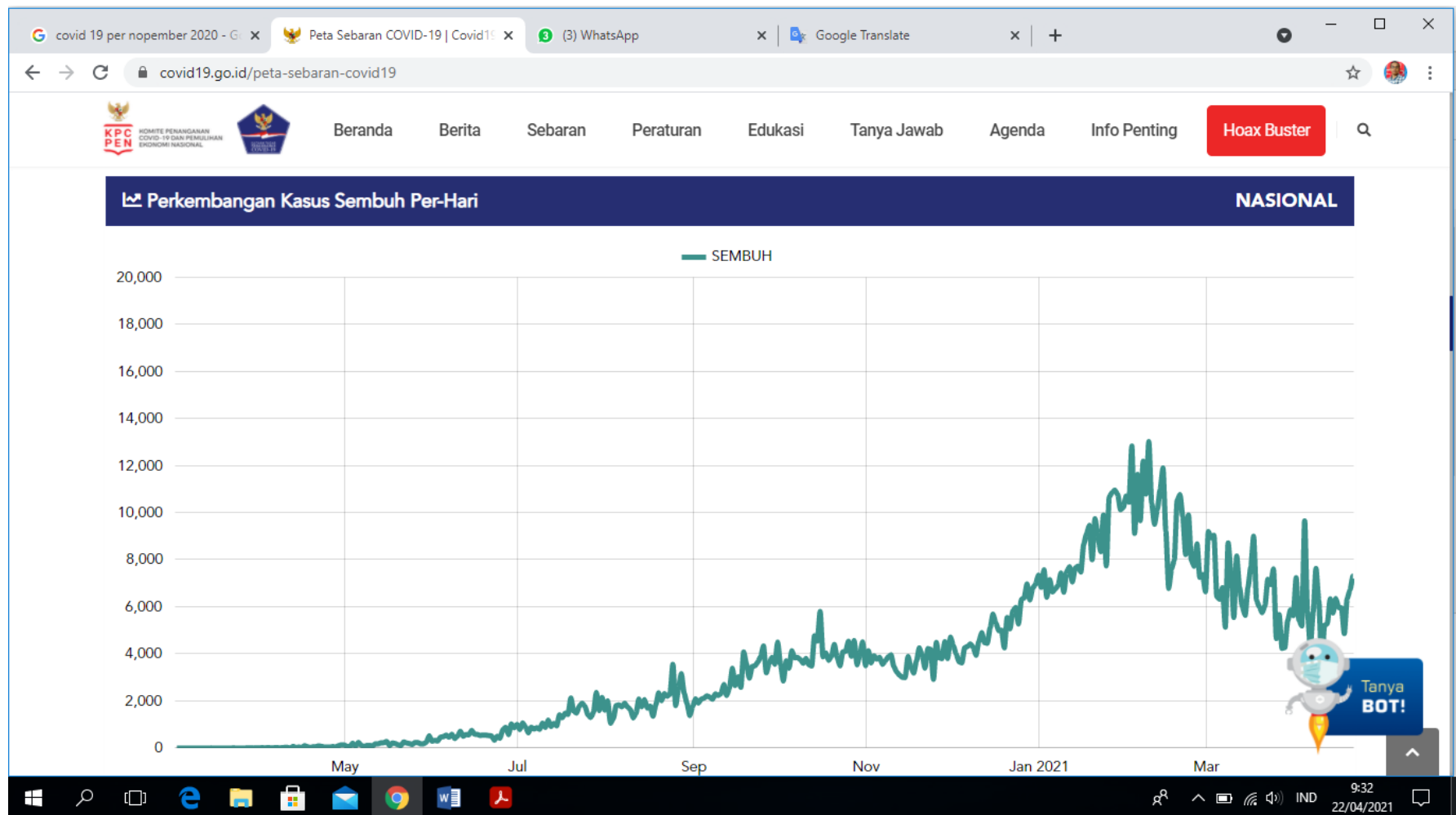

Figure 5 Development of recovered cases for the period May 2020 - March 2021 


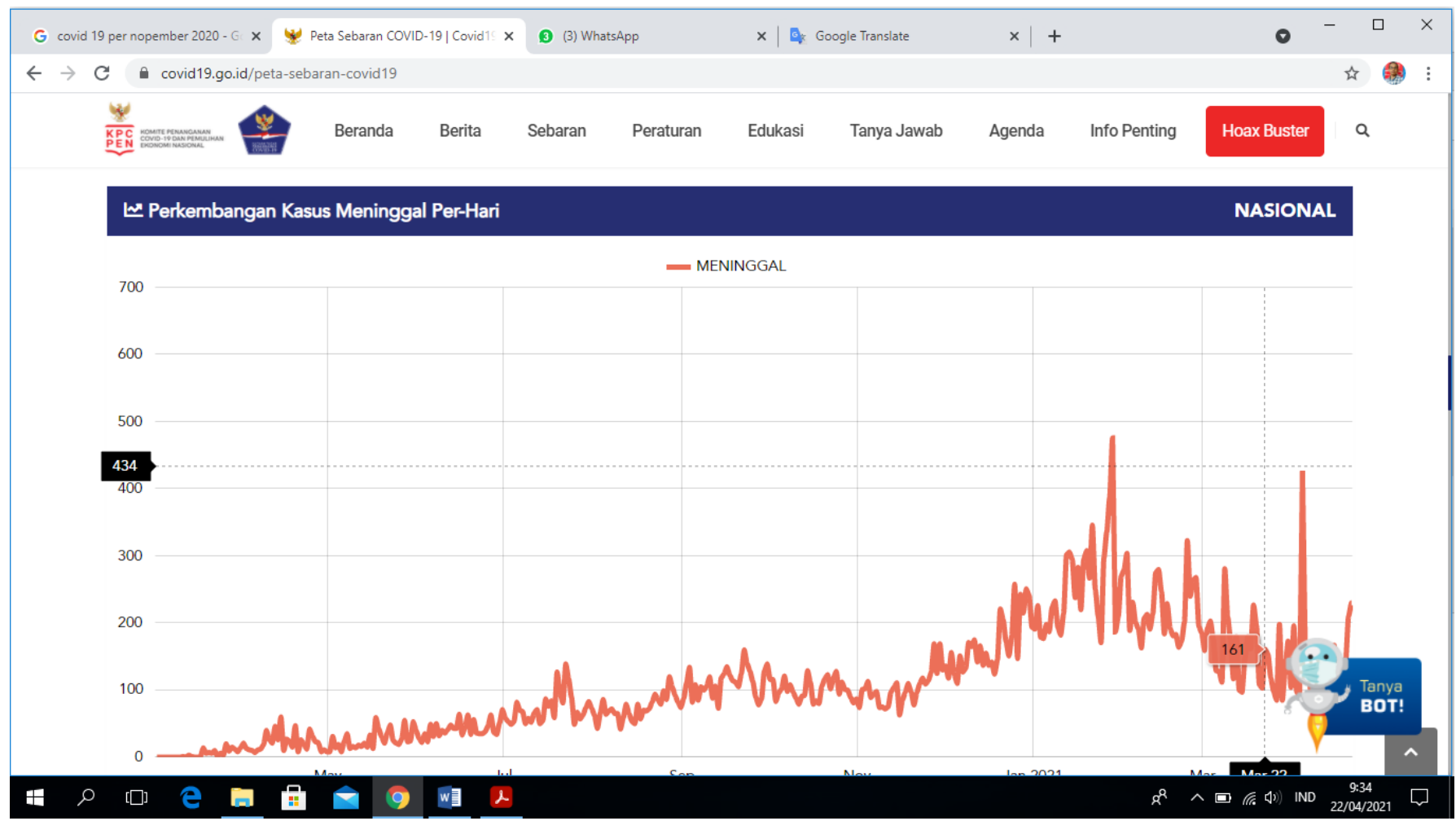

Figure 6 Development of death cases for the period May 2020 to March 2021

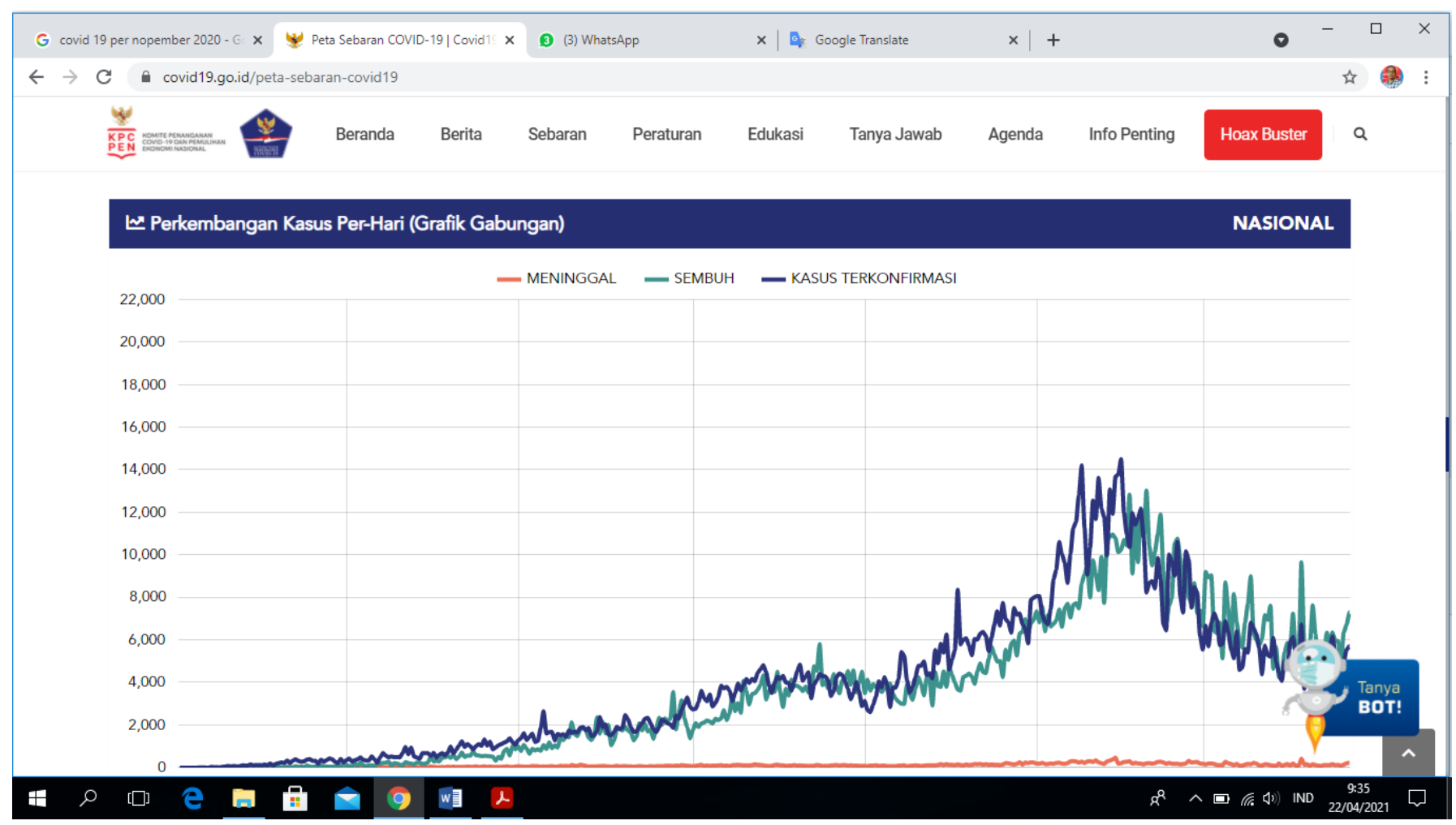

Figure 7 Development of Covid 19 cases (combined chart) 


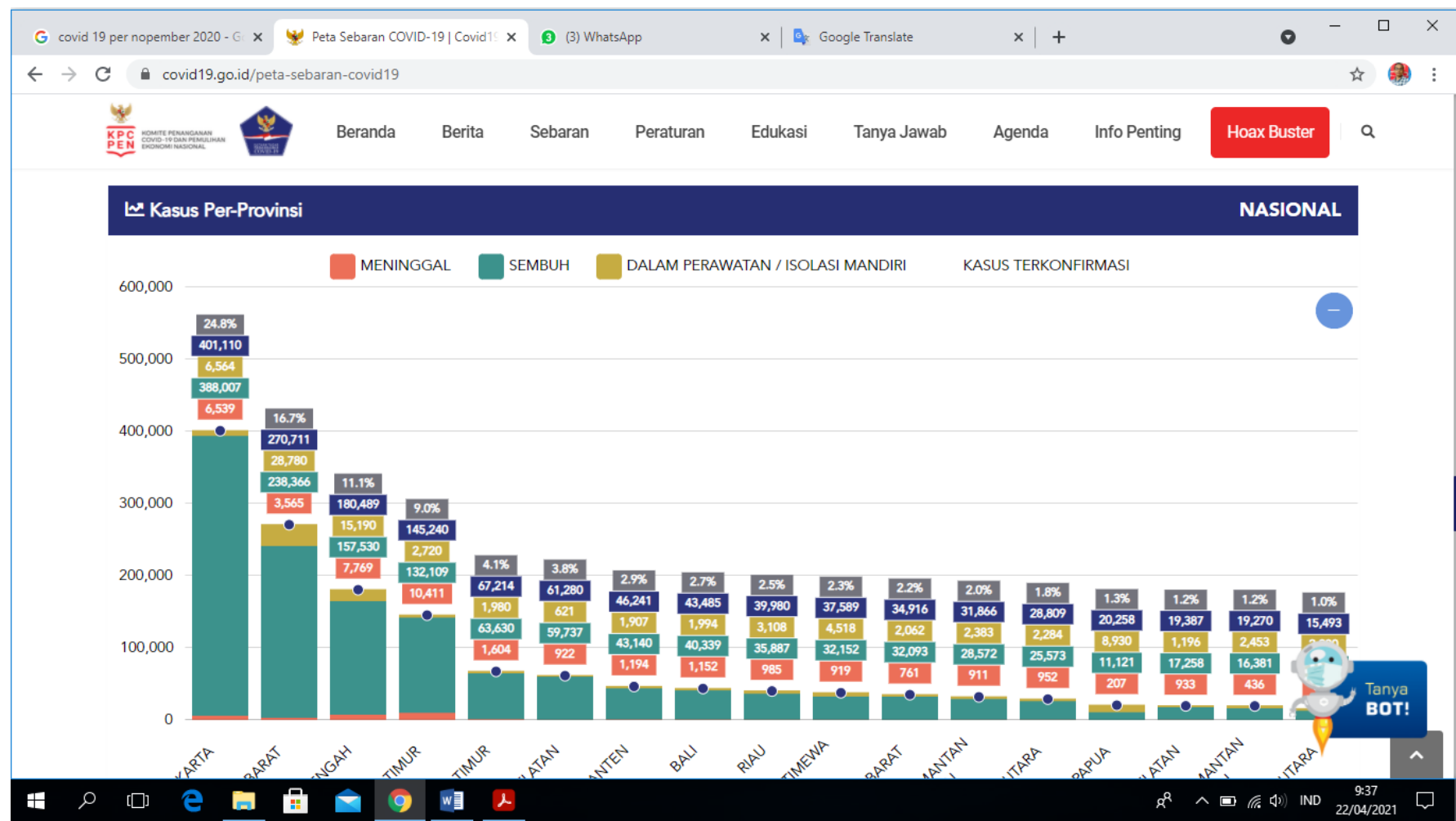

Figure 8 Case by the province in Indonesia

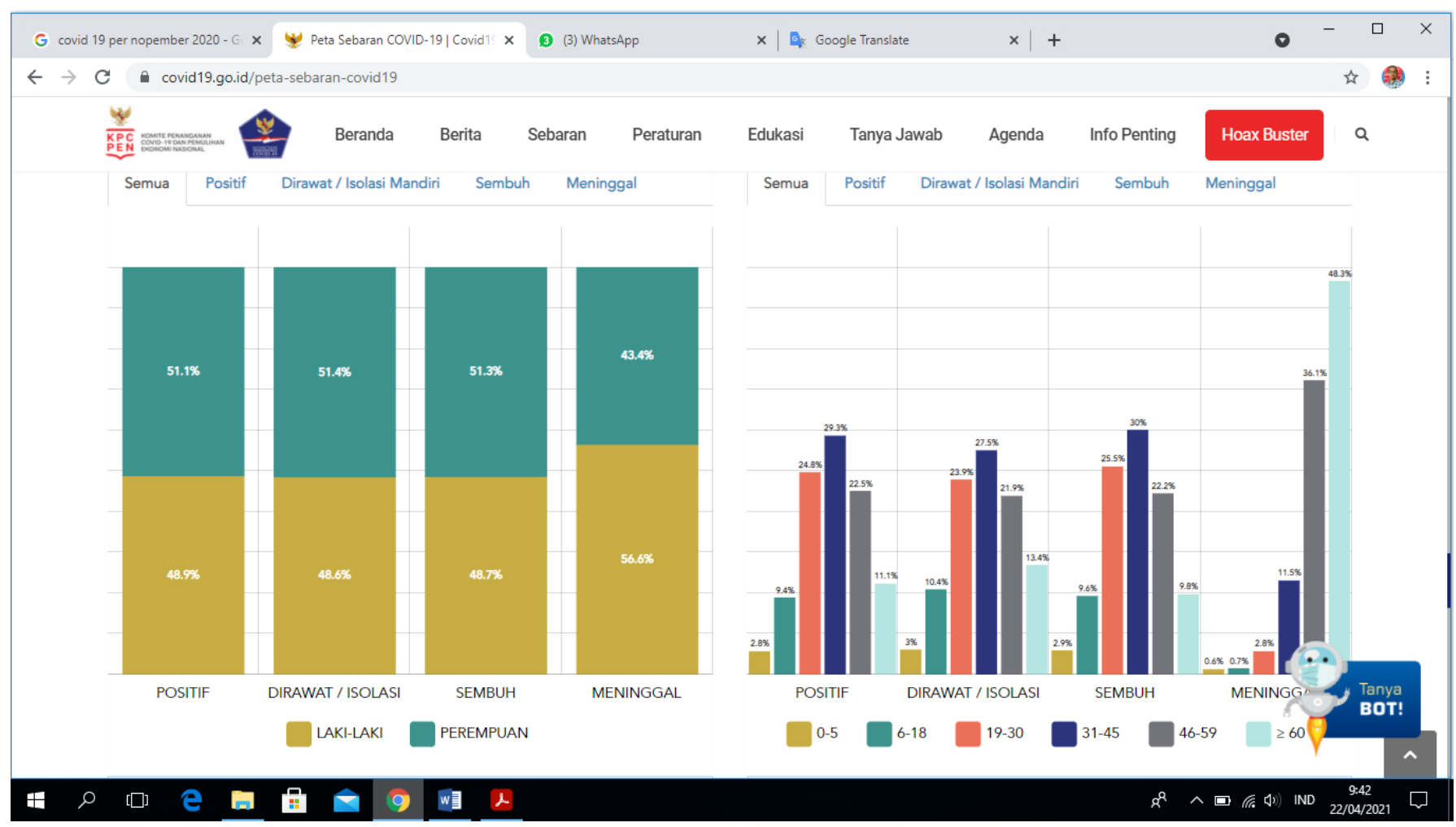

Figure 9 Based on gender and age

Based on figures 4 - 9, based on confirmed positive patient data, the covid 19 case curve increases. It makes the public worry and creates the impression that the government is not ready to solve the Covid 19 
problem. Implementing the PSBB policy is only one choice to reduce the risk of increasing victims, as it is known. PSBB policy is implemented by the authorized official, the Minister who administers government affairs in the health sector. The local government and the private sector are required to adhere to PSBB determined by the Minister. Communities that do not adhere to the implementation of the PSBB be subject to criminal sanctions. One of the legal implications of PSBB is the centralization of authority in policymaking. The local Government requires the approval of the Minister to take steps in preventing Covid PSBB 19. It makes the handling of prevention Covid 19 being slow and having to go through the mechanism. Length so that it has the potential to increase casualties.

If viewed in the fourth paragraph of the Preamble to the 1945 Constitution of the Republic of Indonesia, which states that the State of Indonesia is obliged to protect the Indonesian nation and spilled Indonesian blood, this is not appropriate. To avoid other levels of fatality, the following are efforts made so that the PSBB policy given during the pandemic period is effective by the 1945 Indonesian Constitution: (1) The first step is to have real public information disclosure to the public regarding the map of the spread of COVID-19 patients. The Central and Local Governments ensure real public information disclosure. Information disclosure about Covid 19 refers to Law Number 14 of 2008 concerning demanding public information. The government did not share all information related to handling the coronavirus in line with developing the spread of this virus. Therefore, data openness was initiated because the government needed to convey it to the public. Data on patients who died or were positive to determine the chain of spread of the virus. The impact of the prevailing PSBB, especially on the current economic condition, must guarantee that the lower middle class can meet their needs. As a form of meeting community needs. The state should guarantee the right to life of its people and not demean the dignity of its people. Not only the role of the government in handling the Covid 19 case, but the role of the community in terms of protecting, reminding, and helping each other, especially because the impact of the PSBB in the context of preventing Covid 19 can reduce the negative impact, especially from the implementation of the PSBB policy.

When viewed from several reviews of the PSBB policies selected by the government in uncovering the current Covid 19 case, it is still in the process of being implemented. Still, indeed in several regions in Indonesia, there are also developments with existing policies. However, suppose it is mandated by the 1945 Constitution of the Republic of Indonesia. In that case, many PSBB policies are ineffective because 
people certainly feel that they have not received the law about existing policies made by the current government. It is especially about the state's responsibility for public health and medical personnel, especially in Article 28 paragraph (1) and Article 33 paragraph (3), which explains that health services are the right of every person responsible for the state for its provision. Everyone has the right and is obliged to receive health to an optimal degree, not only concerning individual problems but covering all the factors that contribute to a healthy life and also the right to health and the right to medical services.

To avoid more death rates, following the efforts made to ensure that policies PSBB given during a pandemic will be effective by 1945 . The first step is to perform a real public disclosure to the public about the spread of the virus. Patients COVID-19 and Local Government ensure real public disclosure of information. Information disclosure about Covid 19 is a must at this time. Disclosure of information Covid 19 refers to Act No. 14 of 2008 on Public Information Demands. The government does not disclose all of the information related to coronavirus and the spread of the virus in this condition. Disclosure data has already begun because the government needs to convey data of patients who died or a positive to know the chain of spread of the virus.

The impact of the prevailing PSBB, especially to the current economic condition, which has fallen drastically, must guarantee and ensure that especially the middle and lower class can meet their needs. As a form of fulfillment of the community's needs, the state's obligation to guarantee the community's right to life and not to reduce the dignity of the people. Not only is the role of the government in handling the Covid 19 case, but the role of the public in terms of protecting, reminding, and helping each other, especially because the impact of the PSBB in the context of preventing Covid 19 can reduce the negative impact, especially from the implementation of the PSBB policy.

For the Bandung area, even though some people have received the first and second vaccines, the spread of Covid 19 has not been able to be completely suppressed. It shows in Figure 10 as of 18 April 2021. 


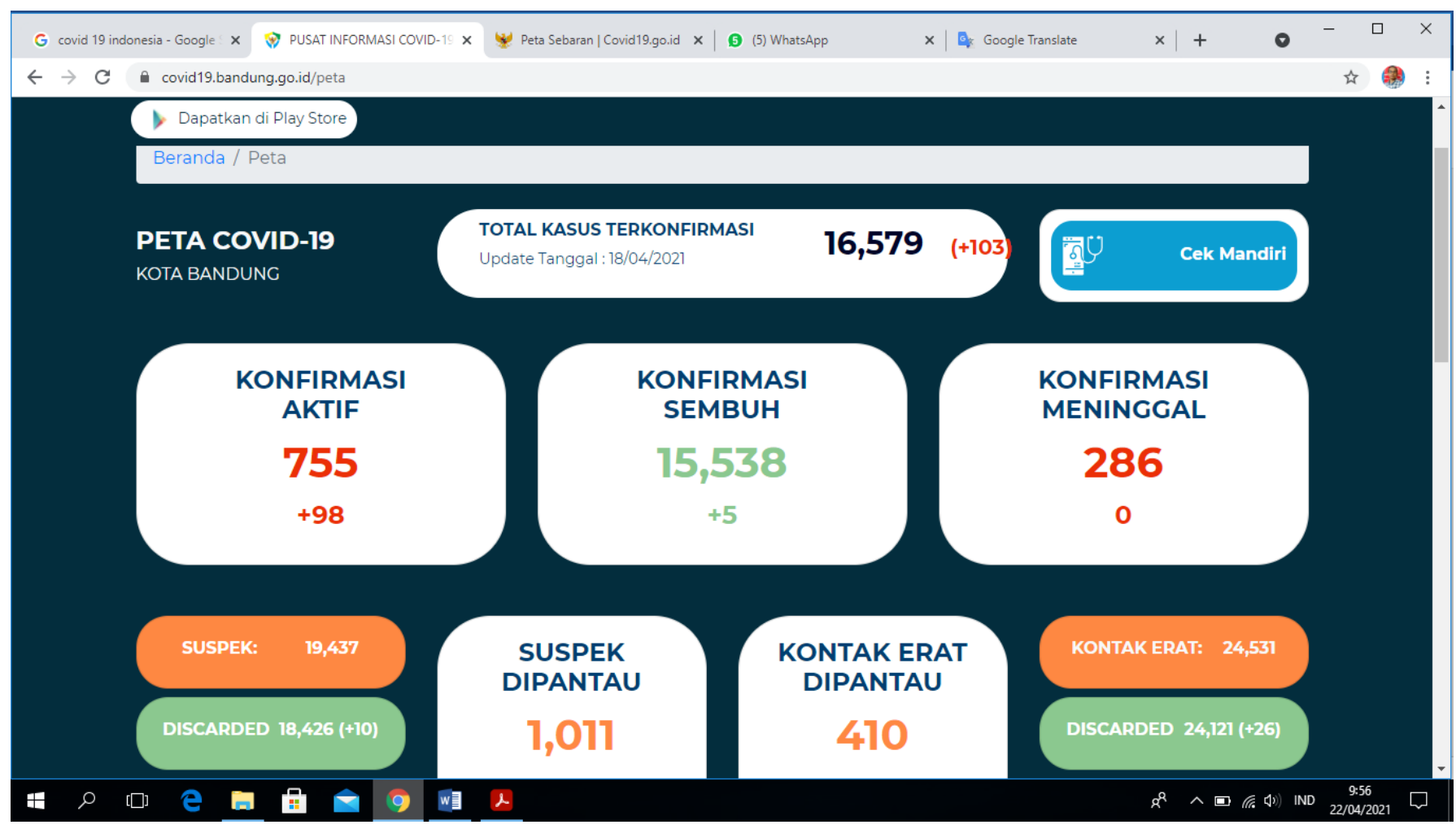

Figure 10 Covid 19 map for Bandung area as of 18 April 2021

To welcome Ramadan 2021, we are trying to make an application system based on the Arduino microcontroller implemented in the area where the author lives. According to reports, there are still two people in the Babakan Tarogong village area confirmed by Covid 19 (source taken from the Android PeduliL Protect application). Using the concept of mapping an area into a matrix system is then combined with the Pythagorean concept to determine the distance of an object from other objects so that the PSBB can be applied in the mosque environment often used for religious facilities with a large number of worshipers.

For application in the field, we try to take a case; for example, there are five worshipers in a position in the mosque when they relax/rest in the mosque, as shown in Figure 4.

First of all, the ultrasonic sensor will capture an object (the congregation of the mosque), each congregation will be mapped its location as shown in Figure 11. After the mapping is done, each congregation will calculate the distance between each congregation using the Pythagorean formula. The results obtained from calculating the distance between congregations can be seen in table 1 . 
In the case study at the mosque, the researcher used PSBB with a distance of 1 meter, not as suggested by the rules that have been ordered by the government, which is 2 meters, this is with the following considerations: (1) Pilgrims who enter the mosque will be limited because the mosque has been planted infrared sensor which functions to count the number of worshipers who are inside the mosque; (2) Every Jamaat who will enter the mosque has lost from checking his body temperature using an infrared-based body temperature sensor MLX9014; (3) At the entrance to the mosque, a hand sanitizer is provided to clean the palms of the hands; (4) For worshipers who do not bring masks, there are mosque officers who will give free masks purchased from mosque cash and donations from mosque congregations to buy masks and handbags.

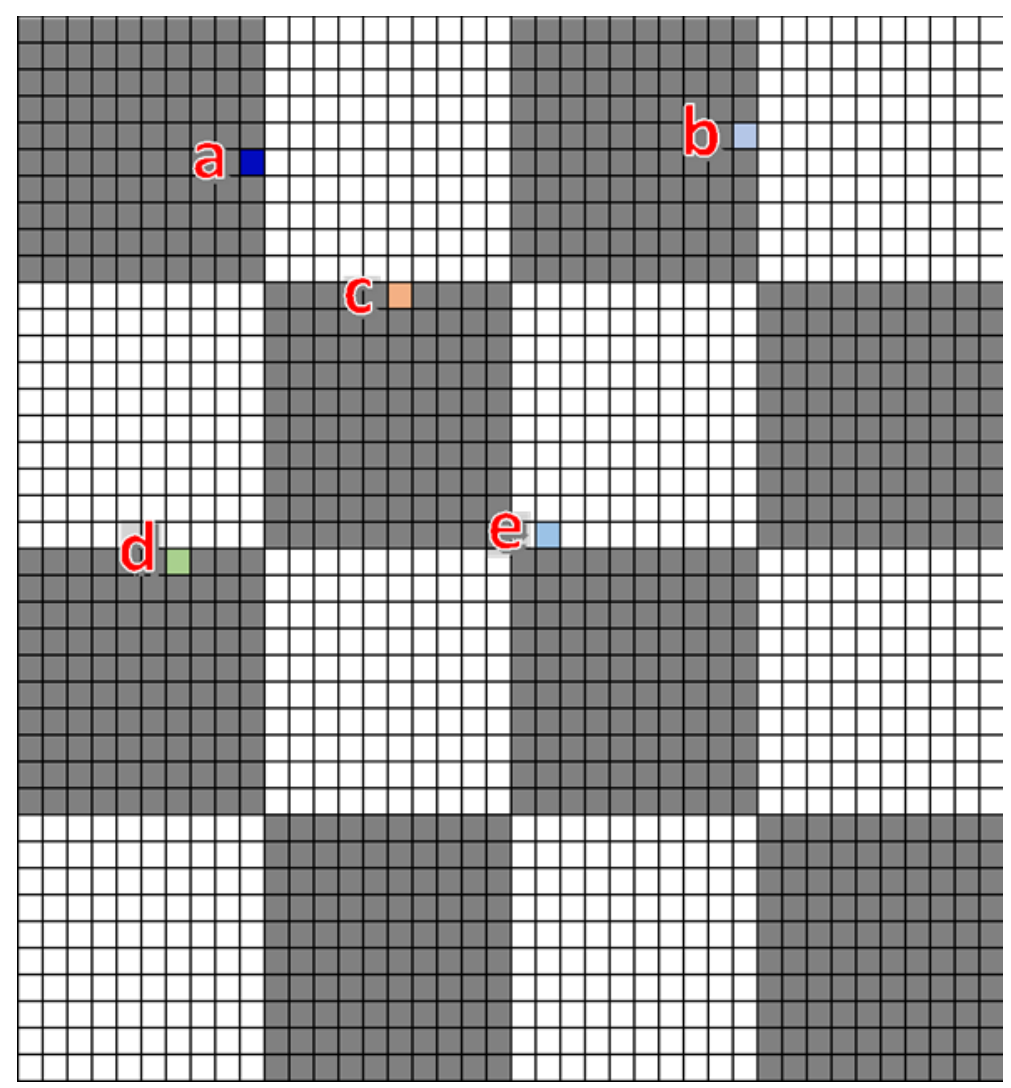

Figure 11 An example of a case of maintaining distance between peoples

To calculate the distance between any two points, we can make a calculation analysis as in Table 1

Tabel 1 Analysis of the calculation of the distance between two objects/worshipers of the mosque with a sample size of 5 worshipers 


\begin{tabular}{|l|l|}
\hline Measuring point & Distance between 2 points (centimeter) \\
\hline a-b & 210,9502311 \\
\hline a-c & 92,19544457 \\
\hline a-d & 164,924225 \\
\hline a-e & 198,4943324 \\
\hline b-c & 198,4943324 \\
\hline b-d & 288,444102 \\
\hline b-e & 183,5755975 \\
\hline c-d & 148,6606875 \\
\hline c-e & 122,0655562 \\
\hline d-e & 161,245155 \\
\hline
\end{tabular}

The results are found that the distance is less than 1 meter. In that case, an alarm in the form of a buzzer will sound to be an indicator to the worshipers who are carrying out worship activities that the system detects that there are two or more worshipers who are less than 1 meter away.

\section{CONCLUSION}

From the measurement results, an object with a distance of less than 1 meter was found, namely, at point ac, the distance between points a and c is 92.19544457 centimeters. Thus, an alarm in a buzzer will notify the people in the mosque. The system finds that the distance between the people in positions a and c is less than 1 meter. With the notification in the form of a buzzer, the people who feel that the distance is less than 1 meter will move to another position; thus, this system can be a reference in maintaining the distance between peoples, especially during the pandemic, so that monitoring of Covid - 19 early warning can run well.

\section{ACKNOWLEDGMENT}

We would like to thank Universitas Komputer Indonesia for supporting this journal.

\section{REFERENCES}

Arfandi, A., \& Supit, Y. 2019. Prototipe Sistem Otomasi Pada Pengisian Depot Air Minum Isi Ulang Berbasis Arduino Uno. Simtek: Jurnal Sistem Informasi dan Teknik Komputer, 4(1): 91-99. 
Dianty, H. 2020. Mendeteksi Suhu Tubuh Menggunakan Infrared dan Arduino. jik-Jurnal Ilmu Komputer, 3(3): 5-9.

Efendi, Y., Rio, U., Muzawi, R., Yanti, R., \& Yenni, H. 2019. Pelatihan Teknologi Mobile Dalam Penerapan Sistem Smart School Pada Smk N 1 Bangko. Jurnal Pengabdian Untuk Mu Negeri, 3(2).

Puspitasari, W. D., \& Ilmi, D. K. 2016. Sistem Pendukung Keputusan Pemilihan Dosen Berprestasi Menggunakan Metode Analytical Hierarchy Process (Ahp). ANTIVIRUS: Jurnal Ilmiah Teknik Informatika, 10(2).

Triono, A. 2017. Analisis Kemampuan Representasi Matematis Siswa Kelas VIII SMP Negeri 3 Tangerang Selatan (Bachelor's thesis).

Soegoto, E. S., Fauzi, F. A., \& Luckyardi, S. 2021. Internet of things for flood and landslide early warning. In Journal of Physics: Conference Series. 1764(1): 012190.

Pratama, W. H., \& Sumitra, I. D. 2020. Utilization of Technology for Early Warning of Natural Disasters in Indonesia. In IOP Conference Series: Materials Science and Engineering. 879(1): 012011.

Gao, Y., Cai, G. Y., Fang, W., Li, H. Y., Wang, S. Y., Chen, L., ... \& Gao, Q. L. 2020. Machine learning based early warning system enables accurate mortality risk prediction for COVID-19. Nature communications, 11(1): 1-10.

Yang, P., Wang, P., Song, Y., Zhang, A., Yuan, G., \& Cui, Y. 2020. A retrospective study on the epidemiological characteristics and establishment of an early warning system of severe COVID-19 patients. Journal of medical virology, 92(10): 2173-2180.

Covino, M., Sandroni, C., Santoro, M., Sabia, L., Simeoni, B., Bocci, M. G., ... \& Franceschi, F. 2020. Predicting intensive care unit admission and death for COVID-19 patients in the emergency department using early warning scores. Resuscitation, 156: 84-91 